\title{
PENGARUH PELATIHAN BERPIKIR POSITIF PADA KETIDAKPUASAN TERHADAP CITRA TUBUH (BODY IMAGE DISSATISFACTION)
}

\author{
Akhmad Mukhlis \\ Fakultas Psikologi \\ Universitas Islam Negeri (UIN) Maulana Malik Ibrahim Malang \\ Jl. Gajayana 50 Malang Telp. 0341-558916 \\ Email: akhmadmukhlis27@gmail.com
}

\begin{abstract}
Abstrak - Penelitian ini bertujuan untuk mengetahui sejauhmana pengaruh pelatihan berpikir positif terhadap ketidakpuasan terhadap citra tubuh. Penelitian ini menggunakan kerangka teori yang mengacu pada the Body Dissatisfaction subscale of the Eating Disorders Inventory-2 (EDI-2) yang disusun oleh Garner dkk.. Subjek adalah remaja perempuan sekolah menengah atas. Subjek memiliki skor EDI-2 tinggi dan bersedia menjadi subjek dibagi kedalam kelompok eksperimen dan kelompok kontrol. Subjek kemudian diminta untuk mengisi EDI-2 sebanyak dua kali yaitu sebelum terapi (pretest), sesaat setelah terapi (posttest) serta diminta untuk menuliskan perkembangan emosinya selama pelatihan. Data dalam penelitian berupa data kuantitatif yang dilengkapi dengan data kualitatif untuk menguatkan penjelasan proses terapi, khususnya dari sisi subjek. Data kuantitatif kemudian dianalisis dengan uji-t dua sampel independen (Independent Sample t-test) dan uji berpasangan (Paired t-test) dengan bantuan program SPSS. Hasil penelitian menunjukkan bahwa pada kelompok eksperimen terdapat perbedaan yang sangat signifikan antara skor EDI-2 pada saat posttest dibandingkan dengan saat pretest peningkatan skor sebesar 17,62 dan $p=0,000(p<0,05)$, sedangkan pada kelompok kontrol tidak ada perbedaan skor yang signifikan $(p=0.824)$. Mengenai hasil-hasil temuan penelitian tersebut akan dipaparkan secara lebih luas di dalam diskusi.
\end{abstract}

Kata Kunci: Pelatihan Berpikir Positif, EDI-2, Remaja Perempuan

PSIKOISLAMIKA. Jurnal Psikologi Islam (JPI) copyright @ 2013 Laboratorium Penelitian, Kajian Psikologi Islam dan Penerbitan. Volume 10. Nomor 1, Tahun 2013

\section{PENDAHULUAN}

Kecantikan merupakan tolok ukur yang paling sering digunakan dalam berbagai kebudayaan untuk menilai perempuan. Di sisi lain, terdapat relatifitas kecantikan dalam masyarakat yang dinilai secara berbeda-beda antar budaya dan antar waktu. Salah satu ukuran kecantikan yang banyak mendapatkan perhatian adalah citra mengenai bentuk tubuh. Di negara-negara non-Barat, seperti di Afrika, tubuh yang gemuk diinterpretasikan sebagai suatu simbol kematangan seksual, kesuburan, kemakmuran, kekuatan, dan kebijaksanaan (Sheinin, dalam
Rice, 1995). Sebaliknya, negara-negara maju dan berkembang (termasuk Indonesia), tubuh yang dianggap cantik bagi kaum perempuan adalah keserasian antara tubuh dan tinggi badan. Kepercayaan tersebut tentu menjadi racikan yang lezat bagi budaya populer saat ini untuk mempromosikan kebencian dan ketakutan terhadap kegemukan secara besar-besaran (Bedah Obesitas Bikin Risiko Bunuh Diri Meningkat, 2010). Budaya populer ini memiliki ciri-ciri bersifat 'instant', memberikan pemuasan sesaat, cenderung dangkal, dan sangat terkait dengan sistem kapitalisme sebagai suatu komoditi (Suryakusuma, 2000; Tomagola, 2000) 
Gencarnya perang terhadap kegemukan dibenarkan oleh Polivy \& McFarlane (1998) dan Rice \& Dolgin (2002) yang menyatakan para perempuan (khususnya remaja) dikonfrontasi dengan pesan yang bertubi-tubi dari media massa bahwa kecantikan, keberhasilan, kebahagiaan, dan harga diri dapat diraih bila para perempuan memiliki bentuk tubuh yang kurus. Sayangnya, konfrontasi media massa dalam berbagai penelitian dianggap berhasil, misalnya dalam penelitian Staffieri (dalam Rice, 1995) menyatakan bahwa sejak usia empat dan lima tahun telah mengembangkan stereotipi-stereotipi yang sangat negatif terhadap kegemukan. Ciriciri kepribadian yang tidak menyenangkan yang diasosiasikan dengan kegemukan antara lain penipu, pemalas, tidak rapi, jelek, kejam, dan bodoh.

Fenomena ketakutan dan kebencian terhadap kegemukan ini bukan hanya berhenti pada diri sendiri, perempuan juga peduli untuk sekedar mengingatkan atau bahkan sampai pada kritik terhadap perempuan lain di sekitarnya (menjadi significant person). Persuasi dari significant person (keluarga dan teman sebaya) menjadi faktor lain perhatian perempuan terhadap bentuk tubuhnya (Moreno \& Thelen; Pike \& Rodin, dalam Vincent \& McCabe, 1999). Akibatnya sejumlah besar remaja perempuan mendiskusikan tentang berat badan dan perilaku diet dengan teman-teman mereka (Mukai; dan Paxton dalam Vincent dan McCabe, 1999).

Sayangnya, seringkali yang dimaksud dengan berat dan bentuk tubuh yang ideal menurut media tersebut bukanlah ideal menurut ukuran kesehatan, yaitu bentuk tubuh kurus dengan berat badan yang berada di bawah normal. Garner dkk. (dalam Dittrich, 2003) menemukan bahwa ukuran ratarata dari perempuan yang dianggap ideal (seperti yang digambarkan oleh para model) telah menjadi semakin kurus dan bertahan pada kisaran 13-19\% di bawah berat badan yang sehat.

Remaja perempuan yang memiliki sikap yang mendukung terhadap persuasi untuk bertubuh ideal menurut ukuran media akan lebih mudah mengalami ketidakpuasan terhadap citra tubuhnya (body image dissatisfaction). Esther (2002) menemukan beberapa fakta, yaitu (1) $62 \%$ subjek penelitian ingin menurunkan berat badan setelah menonton acara peragaan busana dan penampilan para artis di televisi dan (2) $75 \%$ subjek penelitian yang suka membaca artikel tentang bentuk tubuh yang langsing di media cetak merasa tidak puas dengan citra tubuh mereka.

Gonzales-Lavin dan Smolak (dalam Thompson dan Heinberg, 1999) menemukan bahwa remaja perempuan yang menonton televisi lebih dari 8 jam per minggu melaporkan ketidakpuasan terhadap citra tubuh yang secara signifikan lebih tinggi daripada remaja perempuan yang lebih jarang menonton televisi. Hal lain yang lebih memprihatinkan adalah bahwa ketidakpuasan terhadap citra tubuh tidak hanya dialami oleh remaja perempuan yang bertubuh gemuk atau kurus, melainkan juga oleh remaja perempuan yang berat badannya sudah tergolong ideal (Kompas, 21 Agustus 2012).

Beberapa penelitian menemukan bahwa masalah ketidakpuasan terhadap citra tubuh ternyata dapat menimbulkan masalah-masalah lain yang lebih serius. Attie dan Brooks-Gunn; Strong dan Huon (dalam Haugaard, 2001) menyatakan bahwa perempuan yang merasa tidak puas dengan bentuk tubuh mereka akan berisiko lebih tinggi untuk melakukan diet yang serius dan mengalami gangguan makan dibandingkan dengan perempuan yang telah merasa puas dengan bentuk tubuh mereka. Ketidakpuasan terhadap citra tubuh dapat meningkatkan perilaku merokok di kalangan remaja perempuan karena merokok merupakan salah satu metode penurunan berat badan yang umum digunakan oleh remaja masa kini (Berg, dalam Dittrich, 2003).

Guiney dan Furlong (dalam Rice dan Dolgin, 2002) menyatakan bahwa pada remaja perempuan, ketidakpuasan terhadap citra tubuh berdampak pada harga diri yang lebih rendah daripada remaja perempuan yang lain. Penelitian dari Siegel dkk. (dalam Rice \& Dolgin, 2002) menemukan bahwa citra tubuh yang negatif merupakan penyebab utama remaja perempuan menjadi lebih depresif daripada remaja laki-laki. Rodin dkk. (dalam Dittrich, 2003) menambahkan bahwa perasaan devaluasi diri, disforia (depresi), dan tidak berdaya lebih sebabkan karena standar "ideal" budaya yang tidak dapat dicapai oleh kebanyakan perempuan. Bahkan, menurut American Association of University Women (dalam Dittrich, 2003), ketidakpuasan terhadap citra tubuh ini berhubungan dengan risiko bunuh diri pada remaja perempuan.

Paparan fakta diatas menunjukkan betapa serius dampak yang mengancam remaja perempuan akibat ketidakpuasan terhadap citra tubuh (body image dissatisfaction). Perkembangan ilmu psikologi membuka berbagai ruang baru dalam memberikan berbagai alternatif terkait intervensi, salah satunya berupa pelatihan berpikir positif (Sdorow, 1990). Ellis (dalam Corey, 2007) menyatakan seseorang mampu memodifikasi keyakinan-keyakinannya 
dengan melatih kemampuan berpikirnya. Hayes \& Rogers (2008) menambahkan bahwa cara dan pola berpikir seseorang mempengaruhi perilaku dan perasaan yang akan dimunculkan dalam situasi spesifik. Penelitian Loehr (dalam Santrock, 2003) menunjukkan bahwa suasana hati yang negatif memungkinkan untuk marah, merasa bersalah, dan memperbesar kesalahan yang telah terjadi. Berpikir positif berkaitan dengan hidup positif yang berorientasi pada keyakinan. Dengan berpikir positif, seseorang mampu bertahan dalam situasi yang penuh stres seperti ketika mengalami ketidakpuasan terhadap citra tubuh (Brissette dkk. dalam Kivimaki dkk, 2005).

Berdasarkan keterangan di atas, peneliti melihat pentingnya pengembangan model pelatihan berpikir positif untuk meningkatkan penilaian terhadap citra tubuh. Pada penelitian ini, digunakan model berpikir positif Elfiky (2008) yang dikolaborasikan dengan beberapa pendekatan psikologi lainnya. Elfiky (2008) menyebutkan saat seseorang berpikir, informasi yang dipikirkannya akan dimaknai dan pada akhirnya memanifestasikan perasaan tertentu. Oleh sebab itu, berpikir positif pada hakikatnya juga berkaitan erat dengan emosi. Berdasarkan uraian di atas, maka peneliti mengajukan hipotesis terdapat pengaruh pelatihan berpikir positif terhadap penurunan tingkat ketidakpuasan terhadap citra tubuh (body image dissatisfaction).

\section{KERANGKA KERJA TEORITIK}

Menurut Rice (1995), citra tubuh adalah gambaran mental yang dimiliki seseorang tentang tubuhnya yang meliputi pikiran-pikiran, perasaan-perasaan, penilaian-penilaian, sensasi-sensasi, kesadaran, dan perilaku yang terkait dengan tubuhnya. Gardner (dalam Faucher, 2003) mendefinisikan citra tubuh sebagai gambaran yang dimiliki seseorang dalam pikirannya tentang penampilan (misalnya ukuran dan bentuk) tubuhnya, serta sikap yang dibentuk seseorang terhadap karakteristik-karakteristik dari tubuhnya. Jadi terdapat dua komponen dari citra tubuh, yaitu komponen perseptual (bagaimana seseorang memandang tubuhnya sendiri) dan komponen sikap (bagaimana seseorang merasakan tentang penampilan atau tubuh yang dipersepsinya).

Citra tubuh mulai terbentuk pada saat anakanak prasekolah menginternalisasikan pesan-pesan dan standar-standar kecantikan dari masyarakat dan kemudian menilai diri mereka sendiri berdasarkan standar-standar tersebut (Cash, 1998). Dengan cara ini, anak-anak mengembangkan konsepsi tentang apa yang baik (how one should look) dan apa yang buruk (how one should not look) dengan melihat tinggi badan, berat badan, kondisi otot, warna rambut, dan gaya atau merek pakaian mereka.

Citra tubuh bukanlah suatu konsep yang statis, melainkan berkembang melalui interaksi dengan orang lain dan lingkungan sosial, serta mengalami perubahan sepanjang rentang kehidupan sebagai tanggapan terhadap umpan balik dari lingkungan (Freedman, 1986; Rice, 1995; dan Cash, 1998).

Citra tubuh dipengaruhi oleh banyak faktor, meliputi: (a) penilaian atau komentar dari orang lain; (b) pelecehan seksual dan rasial; (c) stigmatisasi; (d) nilai-nilai sosial yang berlaku; (e) perubahanperubahan fisik selama masa pubertas, menopause, dan kehamilan; (f) sosialisasi; (g) bagaimana perasaan seseorang tentang dirinya sendiri; $(h)$ kekerasan, baik verbal, fisik, maupun seksual; dan (i) kondisi-kondisi aktual dari tubuh, seperti penyakit atau disabilitas.

Terdapat beberapa faktor yang mempengaruhi ketidakpuasan terhadap citra tubuh, diantaranya adalah pertama pola standar kecantikan dari setiap budaya yang tidak mungkin dicapai (Rice 1995; dan Brehm, 1999). Kedua adalah keyakinan bahwa kontrol diri dapat memberikan tubuh yang sempurna. Kenyataan bahwa satu-satunya bagian tubuh yang memungkinkan untuk diubah adalah berat badan, sehingga berat badan menjadi pusat perhatian dalam usaha-usaha peningkatan diri (Polivy \& Herman dalam Rice, 1995).

Faktor ketiga adalah ketidakpuasan yang mendalam terhadap diri sendiri dan kehidupan, terutama jika meningkat menjadi kebencian terhadap tubuh, merupakan suatu ekspresi dari harga diri yang rendah dan perasan inadekuat (Leibel dkk., dalam Rice 1995). Keempat adalah kebutuhan akan kontrol di dalam dunia yang terasa tidak terkontrol. Kemampuan mengontrol tubuhnya sendiri menyebabkan seseorang merasa setidaktidaknya mempunyai pengaruh terhadap hidupnya sendiri (Rice, 1995). Kelima hidup dalam budaya yang menekankan kesan awal (first impressions). Menurut Berger dan Kano (dalam Rice, 1995), dalam sebuah budaya yang mengukur nilai seorang perempuan berdasarkan daya tarik tubuhnya, identitas perempuan itu akan menjadi sangat terkait dengan penampilannya.

Ketidakpuasan pada citra tubuh menimbulkan banyak masalah bagi remaja perempuan. Menurut Attie \& Brooks-Gunn; Strong dan Huon (dalam 
Haugaard, 2001), perempuan yang merasa tidak puas dengan bentuk tubuh mereka akan berisiko lebih tinggi untuk melakukan diet yang serius. Hal tersebut ditegaskan oleh Maria dkk. (2001) menemukan adanya hubungan antara ketidakpuasan terhadap citra tubuh dengan kecenderungan gangguan makan (anorexia nervosa dan bulimia nervosa). National Council for Research on Women (dalam Crawford dan Unger, 2000) melaporkan bahwa 90\% kasus gangguan makan dialami oleh para perempuan. Selanjutnya dilaporkan perempuan yang berusia 7-17 tahun saat ini adalah pengguna berat dari pil diet. Salah satu kasus nyata mengenai bahaya Gangguan makan memiliki angka kematian yang tertinggi $(10 \%)$ diantara semua tipe gangguan psikiatri.

Pelatihan berfikir positif adalah proses berpikir berkaitan erat dengan konsentrasi, perasaan, sikap, dan perilaku (Elfiky, 2008). Berpikir positif dapat dideskripsikan sebagai suatu cara berpikir yang lebih menekankan pada sudut pandang dan emosi yang positif, baik terhadap diri sendiri, orang lain maupun situasi yang dihadapi. Pelatihan berpikir positif dapat diidentifikasikan sebagai pelatihan yang menekankan suatu cara berpikir yang lebih menekankan pada sudut pandang dan emosi yang positif, baik terhadap diri sendiri, orang lain maupun situasi yang dihadapi (Elfiky, 2008).

Peneliltian terhadap efek berpikir positif mulai dikembangkan oleh para pakar psikologi positif saat ini. Penelitian Herabadi (2007) juga membuktikan adanya hubungan kebiasaan berpikir secara negatif dengan rendahnya harga diri. Berpikir positif juga membuat individu mampu bertahan dalam situasi yang rawan distres (Brissette dkk., dalam Kivimaki dkk, 2005). Selain itu, Fordyce (dalam Seligman dkk., 2005) juga menemukan bahwa kondisi psikologis yang positif pada diri individu dapat meningkatkan kemampuan untuk menyelesaikan beragam masalah dan tugas. Berpikir positif juga membantu seseorang dalam memberikan sugesti positif pada diri

saat menghadapi kegagalan, saat berperilaku tertentu, dan membangkitkan motivasi (Hill \& Ritt, 2004).

Individu yang cenderung berpikir positif dapat dideteksi melalui beberapa kriteria. Pertama, percaya pada kuasa Tuhan Yang Maha Esa. Kedua, selalu menjauh dari perilaku negatif seperti berbohong, menggunjing, mengadu domba, dan sebagainya. Ketiga, memiliki cara pandang, tujuan, dan alasan menginginkan sesuatu, kapan, serta bagaimana cara mendapatkannya dengan mengerahkan seluruh potensi serta kemungkinan yang ada. Keempat, memiliki keyakinan dan proyeksi tentang sesuatu secara positif. Kelima, selalu mencari jalan keluar dari berbagai masalah yang dihadapi. Keenam, belajar dari masalah dan kesulitan. Ketujuh, tidak membiarkan masalah atau kesulitan mepengaruhi hidupnya. Kedelapan, memiliki rasa percaya diri, menyukai perubahan, dan berani menghadapi tantangan. Kesembilan, hidup dengan cita-cita, perjuangan, dan kesabaran. Terakhir, pandai bergaul dan suka membantu orang lain.

Pelatihan berpikir positif merupakan salah satu pengembangan atas model kognitif transpersonal. Pelatihan berpikir positif dalam penelitian ini dikembangkan dari model pendekatan berpikir positif Elfiky (2008) yang dikombinasikan dengan beberapa pendekatan psikologi, yaitu relaksasi, visualisasi, dan afirmasi. Pelatihan berpikir positif didasarkan pada asumsi bahwa manusia memiliki kesanggupan untuk berpikir, maka manusia mampu untuk melatih dirinya sendiri untuk mengubah atau menghapus keyakinan yang merusak dirinya sendiri (Ellis dalam Corey, 2007).

\section{METODE}

Penelitian ini menggunakan eksperimen yang digunakan peneliti adalah Randomized Pre-Post Test Control Group Design (Latipun, 2002). Teknik sampling yang digunakan dalam penelitian ini melakukan randomisasi subjek kedalam kelompok eksperimen dan kontrol setelah dilakukan pretest. Penelitian ini menggunakan Skala Ketidakpuasan terhadap Citra Tubuh disusun oleh peneliti dengan mengacu pada the Body Dissatisfaction subscale of the Eating Disorders Inventory-2 (EDI-2) yang disusun oleh Garner dkk. (dalam Posavac dkk., 1998).

Skala Ketidakpuasan terhadap Citra Tubuh terdiri dari 23 butir pernyataan. Pengujian validitas yang dilakukan terhadap skala ini adalah validitas isi, yaitu sejauh mana isi butir-butir pernyataan dari skala ini sesuai dengan blueprint yang telah disusun. Berdasarkan uji reliabilitas skala dengan menggunakan program SPSS, diperoleh koefisien reliabilitas Alpha $=0.9001$, dengan validitas butir (korelasi butir-total) yang berkisar antara 0.2746 - 0.7608 .

Uji normalitas penelitian ini menggunakan teknik Kolmogorov Smirnov Goodness of Fit Test. Uji homogenitas dalam penelitian ini menggunakan levene test. Uji hipotesis menggunakan teknik statistik parametrik uji-t dua sampel independen (Independent Sample t-test) dan uji berpasangan (Paired t-test). 
HASIL

Dari hasil uji normalitas menggunakan teknik Kolmogorov Smirnov Goodness of Fit Test pada skala Skala Ketidakpuasan terhadap Citra Tubuh didapatkan hasil pre-test $=0.026$. Sesuai dengan kaidah yang digunakan yaitu $p>0.05$, maka skor skala depresi selain pada saat pre-test memiliki sebaran normal.

Uji homogenitas varians menggunakan teknik Homogenity of Variance One Way Anova. Dari hasil uji Lavene Statistic skala depresi menunjukkan nilai signifikansi pada saat pre-test $=0.279$, post-test $1=$ 0.320 . Sesuai kaidah yang digunakan, maka ketiga nilai pemberian skala tersebut memiliki varians homogen atau sama.

Hasil uji hipotesis independent sample t-test menunjukkan bahwa antara kelompok eksperimen dan kontrol sebelum adanya perlakuan menunjukkan tidak adanya perbedaan signifikan ( $p=0,316>0,05$ dan nilai te sebesar 1,014 < ttabel sebesar 2,018, $\mathrm{dF}=42$ ). Akan tetapi, setelah diberikan perlakuan terdapat perbedaan yang signifikan dimana te > ttabel $=6,607>2,018$ dan $\mathrm{p}=0,000<0,05$. Ini membuktikan bahwa pemberian pelatihan berpikir positif mempengaruhi ketidakpuasan terhadap citra tubuh subjek. Paired sample t-test menunjukkan pada kelompok kontrol tidak ada perubahan signifikan antara sebelum dan setelah perlakuan (-ttabel $\leq$ te $\leq$ ttabel $(-2,074<1,713<2,074)$ serta $p=0,101$ $>0,05)$. Akan tetapi, pada kelompok eksperimen terjadi perubahan yang signifikan antara sebelum dan setelah perlakuan $($ te $>$ ttabel $(11,325>2,086)$ serta $p=0,000<0,05$ ).

\section{DISKUSI}

Berdasarkan pengolahan data diperoleh bahwa pada kelompok eksperimen terdapat peningkatan skor sebesar 17,62 dan $p=0,000(p<0,05)$. Pada kelompok kontrol terlihat tidak ada perbedaan skor yang signifikan $(p>0,05)$. Uji independent sample t-test menunjukkan bahwa perbedaan skor pretest antara kelompok eksperimen dan kontrol adalah tidak signifikan $(p>0,05)$. Perbedaan terlihat setelah perlakuan yang ditunjukkan adanya peningkatan skor yang signifikan pada kelompok eksperimen (te $=11,325>$ ttabel $=2,086, p<0,05)$ dan subjek kontrol tidak menunjukkan perbedaan skor yang signifikan te $=1,713 \leq$ ttabel $=2,074, p>0,05$ ).

Dengan demikian hipotesis penelitian dapat diterima yaitu ada pengaruh pelatihan berpikir positif terhadap penurunan tingkat ketidakpuasan terhadap citra tubuh. Menurut analisa peneliti, hasil tersebut tidak lepas dari beberapa faktor dalam penelitian seperti pelaksanaan penelitian, subjek penelitian, dan juga sekolah tempat penelitian.

Pelaksanaan penelitian menjadi kunci keberhasilan pelatihan berpikir positif dalam penelitian ini. Pelasanaan penelitian ini terkait dalam beberapa aspek seperti materi pelatihan, intensitas dan jadwal pelatihan, metode pelatihan, pemilihan fasilitator dan juga dinamika kelompok pelatihan. Materi dalam pelatihan ini dikembangkan atas model kognitif transpersonal. Pelatihan berpikir positif dalam penelitian ini dikembangkan dari model pendekatan berpikir positif Elfiky (2008) yang dikombinasikan dengan beberapa pendekatan psikologi, yaitu relaksasi, visualisasi, dan afirmasi. Pelatihan berpikir positif didasarkan pada asumsi bahwa manusia memiliki kesanggupan untuk berpikir, maka manusia mampu untuk melatih dirinya sendiri untuk mengubah atau menghapus keyakinan yang merusak dirinya sendiri (Ellis dalam Corey, 2007). Dalam tinjauan pustaka dijelaskan bahwa akibat ketidakpuasan terhadap citra tubuh meliputi gangguan makan, diet yang justru menyebabkan kelebihan berat badan, olahraga yang berlebihan (kadang-kadang disebut exercise bulimia) dan perilaku-perilaku menghukum diri yang lain. Pelatihan berpikir positif mampu mengarahkan subjek untuk merubah citra kecantikan melalui analisa diri budaya subjek.

Faktor penyebab lain ketidakpuasan terhadap citra tubuh adalah significant person (keluarga dan teman sebaya) penelitian ini didekati dengan pembentukan dinamika kelompok pelatihan yang solid. Strategi mengatasi masalah (coping) dalam penelitian ini juga dikembangkan secara fleksibel dan kreatif dalam setiap materi, khususnya materi optimisme.

Selain materi pelatihan secara inti, pelatihan ini juga memberikan materi tambahan berupa ice breaking dan membangun harapan. Materi ini dimaksudkan dapat mendorong subyek penelitian untuk dapat mengikuti pelatihan dengan perasaan nyaman dan santai, sehingga subyek dapat terlibat sepenuhnya untuk mengikuti jalannya pelatihan. Kondisi rileks yang diciptakan tetapi tetap serius ini dapat membantu peserta pelatihan untuk tetap dalam kondisi optimal, sehingga peserta pelatihan dapat menggunakan kemampuan berpikirnya dalam taraf optimal.

Intensitas dan jadwal dalam pelatihan ini berhasil 
memberikan efek untuk mereduksi tekanan pada subjek. Hal tersebut tidak terlepas dari pengambilan jadwal pada hari sabtu untuk mengurangi efek menekan, mengingat hari aktif yang lain digunakan sebagai jadwal pelajaran.

Metode dengan menggunakan pendekatan suportif dalam penelitian ini mampu memberikan dorongan pada subjek tanpa ada unsur penilaian (Liebmann, 1986; Ballou, 1995). Variasi metode dalam pelatihan (ceramah, diskusi, latihan atau penugasan, game, presentasi dan juga wawancara individual) berhasil memberikan nuansa lebih hidup, rileks, ceria, menantang tapi santai dan lebih bersemangat selama berlangsungnya terapi sehingga berhasil menurunkan tingkat ketidakpuasan terhadap citra tubuh subjek. Selain itu metode ini juga dapat mendorong subjek pelatihan untuk berlatih memahami ide dan pendapat orang lain, menerima perbedaan, dan mendiskusikan perbedaan atau ketidaksepahaman. Hal lain yang dicapai dalam metode ini adalah timbulnya keberanian subjek untuk mengemukakan pendapat, kemauan subyek untuk bertanya, keterlibatan subjek dalam memerankan suatu tugas serta keberanian subyek untuk menyampaikan informasi kepada orang lain di depan kelompok. Metode dalam kegiatan ini juga terbukti meningkatkan keterampilan sosial subjek dalam bentuk presentasi, komunikasi dan membangun relasi sosial dengan orang lain dalam forum kelompok.

Dinamika kelompok dalam pelatihan dipilih dengan mengkategorikan kelompok dalam kategori besar (Juul \& Schuler, 1983; Wallin \& Durr, 2002; Isaksson et al., 2009; Gussak, 2009). Dengan heterogenitas status sosial, jenis ketidakpuasan dan peran significant other, setiap subjek dalam kelompok akan mempelajari perbedaan, jenis masalah dan juga tingkat tekanan sehingga menjadi bahan evaluasi, penerimaan, dan koping bagi setiap subjek.

Temuan ini tentunya memperlihatkan betapa besarnya pengaruh lingkungan internal subjek (keluarga) terhadap peningkatan sekaligus penurunan ketidakpuasan terhadap citra diri. Peningkatan atau penurunan tersebut tercermin dalam perilaku, seperti perasaan sedih, malu, penyalahan terhadap diri sendiri dan tidak menghargai diri sendiri.

\section{KESIMPULAN}

Berdasarkan uraian di atas, dapat disimpulkan bahwa pelatihan berpikir positif memiliki pengaruh dalam menurunkan tingkat ketidakpuasan terhadap citra tubuh remaja perempuan. Ketidakpuasan terhadap citra tubuh kelompok eksperimen terbukti lebih rendah dibandingkan dengan kelompok kontrol. Signifikansi peningkatan skor ditunjukkan oleh nilai signifikansi yang kurang dari taraf nyata $(0,000<0,005)$.

\section{DAFTAR PUSTAKA}

Bedah Obesitas Bikin Risiko Bunuh Diri Meningkat. http://www. Go4HealthyLife.com. Diunduh 10 September 2012

Brehm, B. A. 1999. Body dissatisfaction: causes and consequences. http://www. fitnessworld.com/ info/infopages/library/labnotes/labnotes0399. html. Diunduh 10 September 2012

Cash, T. F. 1998. The emergence of negative body images. In E. A. Blechman and K. D. Brownell (Ed.). Behavioral medicine and women: a comprehensive handbook (pp. 386-391). New York: The Guilford Press.

Dittrich, L. 2003. About-face facts on body image. http://www.about-face.org/r/facts/bi.html. Diunduh 10 September 2012

Elfiky, I. 2009. Terapi Berpikir Positif. Jakarta: Zaman

Esther. 2002. Hubungan antara sikap terhadap persuasi untuk bertubuh ideal menurut media dan harga diri dengan body dissatisfaction. Skripsi, tidak diterbitkan, Fakultas Psikologi Universitas Surabaya, Surabaya.

Faucher, C. 2003. Cognitive behavior therapy as a treatment for body image dissatisfaction. http://www.varderbilt. edu/AnS/psychology/ health_psychology/BI_Therapy.htm. Diunduh 10 September 2012

Haugaard, J. J. 2001. Problematic behaviors during adolescence. New York: McGraw-Hill.

Hayes, P. \& Rogers, J. 2008. NLP - Neuro-Linguistic Programming- for the Quantum Change. Yogyakarta: Pustaka Baca

Hill, N. \& Ritt, M.J. 2004. Keys to Positive Thinking. Jakarta: Bhuana Ilmu Populer 
Kivimaki., dkk. 2005. Optimism and Pessimism as Predictors of Change in Health After Death or Onset of Severe Illness in Family. Journal of Health Psychology, Vol. 24, No. 4, 413-421

Latipun. 2002. Psikologi Eksperimen. Malang: UMM Press

Polivy, J. and McFarlane, T. L. 1998. Dieting, exercise, and body weight. In E. A. Blechman and K. D. Brownell (Ed.). Behavioral medicine and women: a comprehensive handbook ( $\mathrm{pp}$. 369-373). New York: The Guilford Press.

Posavac, H. D., Posavac, S. S., Posavac, E. J. 1998. Exposure to media images of female attractiveness and concern with body weight among young women. Sex Roles: A Journal of Research, Feb.

Rice, C. 1995. Promoting healthy body image: a guide for program planners: http://www.opc. on.ca/beststart/bodyimg/httoc.html. Diunduh 10 September 2012

Rice, F. P. dan Dolgin, K. G. 2002. The adolescent: development, relationships, and culture (10th ed.). Boston: Allyn and Bacon.
Ririh, N. 2012. Pengendalian Diri Kunci Cegah Kegemukan. http://www.kompas.com. Diunduh 10 September 2012

Santrock, J. W. 2003. Adolescence: perkembangan remaja (edisi keenam) (S. B. Adelar dan S. Saragih, Pengalih bhs.). Jakarta: Penerbit Erlangga.

Suryakusuma, J. 2000. Perempuan, Pornografi, dan Budaya Pop. Jurnal Perempuan: Perempuan \& Budaya Pop, XIII (Maret-April-Mei), 33-35.

Thompson, J. K. and Heinberg, L. J. 1999. The media's influence on body image disturbance and eating disorders: we've reviled them, now can we rehabilitate them? Journal of Social Issues, 55(2), 339-353.

Tomagola, T. A. 2000. "Popular culture, kapitalisme, dan patriarki, sangat berkait”. Jurnal Perempuan: Perempuan \& Budaya Pop, XIII (Maret-AprilMei), 11-14.

Vincent, M. A. and McCabe, M. P. 2000. Gender differences among adolescents in family, and peer influences on body dissatisfaction, weight loss, and binge eating behaviors. Journal of Youth and Adolescence, 29(2), 205-221. 